\title{
NOTE
}

\section{Natural and experimental infection of white spot syndrome virus (WSSV) in benthic larvae of mud crab Scylla serrata}

\author{
Li-Li Chen ${ }^{1}$, Chu-Fang Lo ${ }^{1}$, Ya-Lin Chiu ${ }^{1}$, Chen-Fang Chang ${ }^{2}$, Guang-Hsiung Kou ${ }^{1, *}$ \\ 'Department of Zoology, National Taiwan University, Taipei, Taiwan, ROC \\ ${ }^{2}$ Tung Kang Marine Laboratory, Taiwan Fisheries Research Institute, Tung Kang, Ping Tung, Taiwan, ROC
}

\begin{abstract}
White spot syndrome virus (WSSV), the causative agent of white spot syndrome in shrimp, has a wide host range which extends to crabs, copepods and other arthropods. In this study, benthic larvae of the mud crab Scylla serrata were captured from Taiwan's coastal waters and screened for the presence of WSSV by polymerase chain reaction (PCR) and in situ hybridization. WSSV was detected in around $60 \%$ of the larvae, and this prevalence rate remained fairly constant when the captured larvae were subsequently maintained in an aerated system in the laboratory. WSSV-free larvae obtained from a hatchery were challenged by immersion in a WSSV inoculum. Fifteen days after challenge, cumulative mortality in the experimental group reached $43 \%$ compared to $20 \%$ in the control group. PCR detection of WSSV in both moribund and surviving specimens clearly implicated the virus as the cause of death in most cases. Histological and in situ hybridization data confirmed that WSSV tissue tropism in Scylla serrata crab larvae is similar to that found in shrimp.
\end{abstract}

KEY WORDS: Natural infection - WSSV - Benthic larvae Crab seeds . Scylla serrata. Tissue tropism. PCR

White spot syndrome virus (WSSV) is the causative agent of a disease which has led to mass mortalities of cultured shrimps in Taiwan and many other countries. WSSV has a wide host range and it has been observed not only in shrimps but also in crabs and other arthropods such as copepods, insects and pest prawns (Lo et al. 1996a).

Natural WSSV infections have been found in captured and cultured specimens of the mud crab Scylla serrata both in Taiwan (Lo et al. 1996a) and elsewhere (Flegel 1997, Kanchanaphum et al. 1998). It is also known that mortality can result when adults of this

\footnotetext{
· Corresponding author. E-mail: ghkou@ccms.ntu.edu.tw
}

commercially valuable species are infected with WSSV by injection (Supamattaya et al. 1998). To date, however, although $S$. serrata crab seeds (benthic and megalopa crab larvae are commonly referred to by farmers as crab 'seeds') used for stocking culture ponds are almost invariably caught from the wild, there have been no investigations of the prevalence of WSSV in these wild populations. In the present study we therefore use PCR to screen for the presence of WSSV in $S$. serrata larvae captured from the coastal waters of south Taiwan. We also subject WSSV-free larvae to experimental challenge by immersion in a WSSV inoculum.

Materials and methods. Experimental infection: Benthic Scylla serrata larvae with a carapace width of $1 \mathrm{~cm}$ were supplied by a crab hatchery in Tung Kang, south Taiwan. These larvae were hatched from eggs derived from wild-caught WSSV-free breeder crabs. Randomly selected specimens were checked using WSSV diagnostic 2-step PCR (Lo et al. 1998) and were all found to be PCR negative.

WSSV inoculum was prepared from serously infected (i.e. 1-step PCR positive; Lo et al. 1996b) black tiger shrimp Penaeus monodon. Carapace and integument tissue ( $5 \mathrm{~g}$ ) was minced and then homogenized in $40 \mathrm{ml}$ sterile seawater $(12.5 \% \mathrm{w} / \mathrm{v})$. After centrifugation $\left(1000 \times g\right.$ for $10 \mathrm{~min}$ at $\left.4^{\circ} \mathrm{C}\right)$, the supernatant was filtered through a $0.45 \mu \mathrm{m}$ membrane and used immediately. A blank (control) inoculum was similarly prepared from a 2-step WSSV-negative shrimp.

The experimental group ( $n=180$ ) was challenged by immersion for $2 \mathrm{~h}$ in an aerated tank containing viral stock solution diluted 1:150 with sterile seawater (total volume $=6 \mathrm{l})$. The control group $(\mathrm{n}=260)$ was similarly treated using the blank inoculum. After immersion, the larvae were removed from the tank and washed twice with sterile seawater. Each group was then randomly 
separated into 3 subgroups $(\mathrm{n}=60)$, and each subgroup was placed in an aerated $30 \mathrm{l}$ plastic tank. The larvae were maintained at $27 \pm 2^{\circ} \mathrm{C}$ and fed with artificial feed once a day for the duration of the $14 \mathrm{~d}$ experiment. Mortalities were recorded daily for each group, and dead specimens were removed from the tanks each day. All dead individuals were checked for the presence of WSSV by using the DNA extracted from the whole body in 2-step PCR (Lo et al. 1996a,b).

In situ hybridization and H\&E staining: At $6 \mathrm{~h}, 12 \mathrm{~h}$, $24 \mathrm{~h}, 2 \mathrm{~d}, 4 \mathrm{~d}, 6 \mathrm{~d}, 8 \mathrm{~d}, 10 \mathrm{~d}$ and $12 \mathrm{~d}$ after challenge, several randomly selected moribund individuals from the above groups were also fixed for histology and in situ hybridization analysis under a light microscope. The DNA probe for in situ hybridization was prepared from a pms146 PCR product (Lo et al. 1996b) and nonradioactively labeled with digoxygenin-dNTP (Boehringer Mannheim Biochemical) using a random priming method. Specimens were fixed in Davidson's fixative. Tissue sectioning and the hybridization procedure was carried out as previously described (Chang et al. 1996, Lo et al. 1997). For H\&E staining, tissues were treated with Davidson's fixative for $48 \mathrm{~h}$, then sectioned and stained with hematoxylin and eosin.

Wild-captured benthic larvae: In the course of 4 field trips to the same collecting area during August and September 1998, benthic larvae of Scylla serrata ( 1.5 to $2 \mathrm{~cm}$ carapace width) were captured from their natural enviromment in the coastal waters around southern Taiwan and immediately transported to the nearby Tung Kang Marine Laboratory of the Taiwan Fisheries Research Institute in Ping Tung Prefecture. From each batch of collected larvae, DNA was extracted (Lo et al. 1998) from randomly chosen specimens ( $n=10$ or 15 ). The DNA was not extracted from any specific organ, but from a mixture of many tissues excluding only the hepatopancreas. The extracted DNA was then tested for the presence of WSSV using a commercial kit (AcuGen Asia Co., Ltd, Taipei, Taiwan) based on a more recently developed 1-step nested WSSV PCR protocol (Lo et al. 1998) that classifies a WSSV infection into 1 of 4 levels. The interpretation of these 4 levels of infection in terms of the diagnoses made by the 2step riesied PCR proiucoi used in inte firsi part of this study is described in Table 1.

The crabs collected on the fourth field trip (September 17) were also used in a followup study. Specimens from this group that were not used for the initial WSSV screening ( $\mathrm{n}=104$ ) were subsequently cultured for $14 \mathrm{~d}$ in the laboratory. To prevent cannibalism, each larva was maintained and fed separately in its own cell in a wire-mesh grid
Table 1 Interpretation of the diagnoses made by the PCR protocols used in this study

\begin{tabular}{|c|c|c|}
\hline $\begin{array}{l}\text { No. of copies of DNA } \\
\text { template in initial } \\
\text { PCR reaction mixture }\end{array}$ & $\begin{array}{l}\text { Diagnosis by } \\
1 \text {-step nested } \\
\text { PCR }^{\mathrm{C}}\end{array}$ & $\begin{array}{l}\text { Diagnosis by } \\
\text { 2-step nested } \\
\text { PCR }^{\mathrm{b}}\end{array}$ \\
\hline$>2 \times 10^{3}$ & Level 1 & 1-step \\
\hline $2 \times 10^{3}$ & Level 2 & 1- or 2-step \\
\hline $2 \times 10^{2}$ & Level 3 & 2-step \\
\hline $2 \times 10^{1}$ & Level 4 & 2-step \\
\hline$<2 \times 10^{1}$ & Negative & Negative \\
\hline \multicolumn{3}{|c|}{${ }^{\mathrm{d}}$ Based on Lo et al. (1998); ${ }^{\mathrm{b}}$ based on Lo et al. (1996b) } \\
\hline
\end{tabular}

apparatus equipped with a seawater flow-through system and aeration. To minimize the chance of WSSV infection from food, the larvae were fed only with an artificial diet. Carcasses and molted shells were collected several times a day, and tissue samples $(100 \mathrm{mg}$ ) were extracted using a commercially available kit (AcuGen Asia Co., Ltd, Taipei, Taiwan) developed from a newer and more convenient DNA extraction protocol (Lo et al. 1996a, 1998). Another DNA extraction method, based on Lo et al. (1996b), was then used to test the extracted samples for the presence of WSSV DNA. Because the primer sets compete for the DNA templates of virus and shrimp that co-exist in the extraction mixture, the PCR results were divided into 4 levels. Levels 1 and 2 indicated a higher quantity of virus in the specimen, and Levels 3 and 4 indicated a lower quantity (Lo et al. 1998). At the end of the $14 \mathrm{~d}$ culture period, 15 of the surviving larvae were chosen at random and also subjected to the same AcuGen DNA extraction and testing products.

Results. Experimental infection: Cumulative Scylla serrata mortalities are shown in Fig. 1. Almost $70 \%$

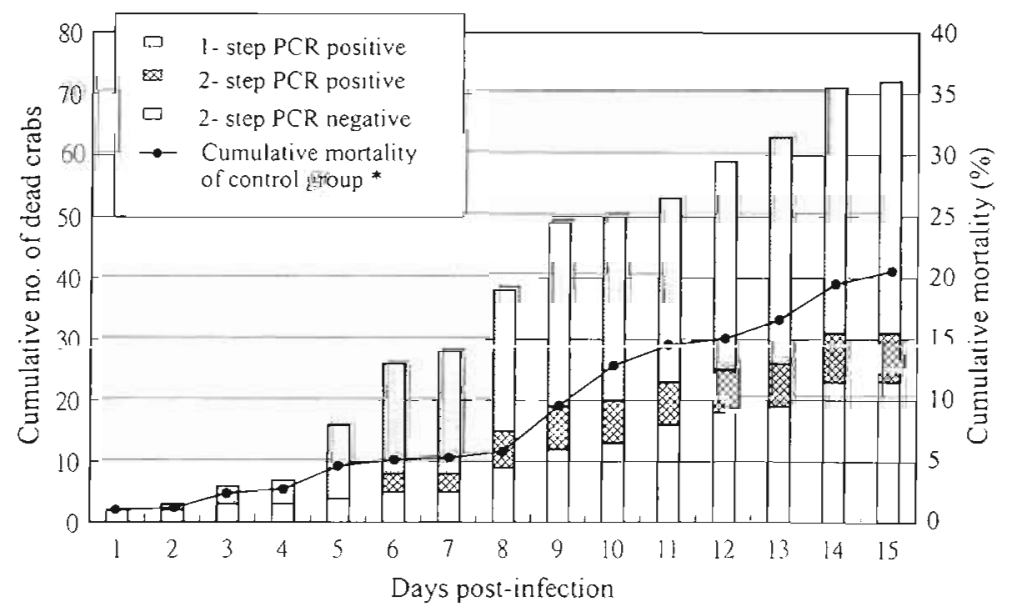

Fig. 1. Scylla serrata. Time-course mortality analysis for mud crabs experimentally challenged with WSSV infection. "WSSV was not detected in any of the crabs from the control group 
(49/71) of the carcasses in the experimental group were PCR positive ( 8 were 2 -step positive only; 41 were both 1 - and 2-step positive), while none of the carcasses or survivors were positive in the control group. At Day 15 post-challenge, WSSV was also detected in $33 \%$ (24/72) of the tested survivors. H\&E staining and in situ hybridization detected no obvious histopathological change after $24 \mathrm{~h}$ infection (data not shown) but at $2 \mathrm{~d}$ post infection, cell degeneration and positive hybridization signals were frequently observed, especially in the external organs (gill and integument) (Fig 2A-D) Subsequently almost all the organs, both internal and external, were infected by WSSV (Fig. 2).
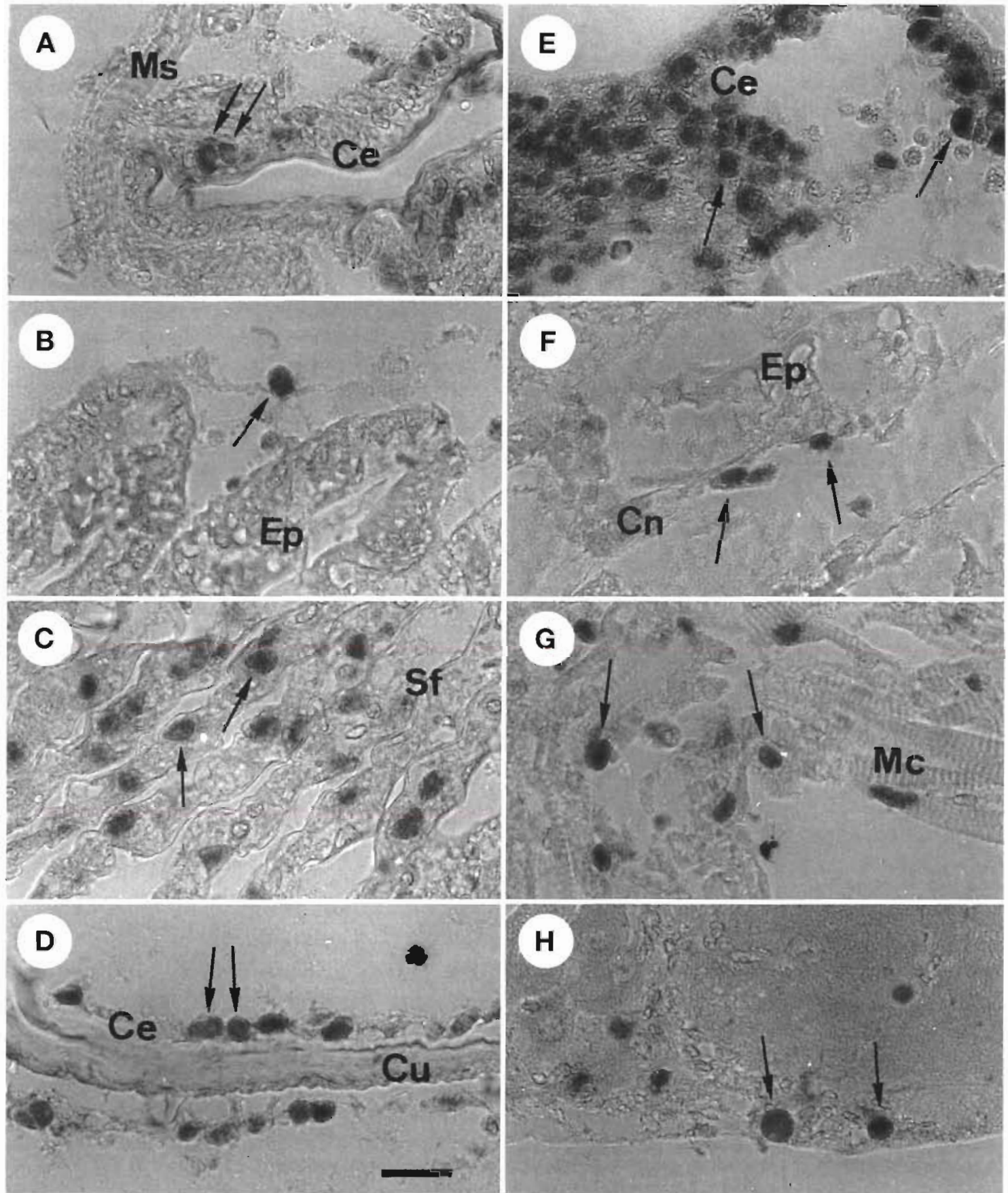

Fig. 2. Scylla serrata. Detection of WSSV DNA in tissue of expermentally unfected moribund mud crabs by H\&E stain and in situ hybridization (A-D) $2 \mathrm{~d}$ and $(E-H) 6$ d after challenge. Positive signals were detected in (A, E) stomach, (B, F) hepatopancreas, (C) gill; (D) integument; (G) heart; and (H) nervous tıssue. Arrows indicate WSSV-infected cells Ce: cuticular epithelium; $\mathrm{Cn}$ : connective tissue; Cu: cuticle; Ep: epithelıum cell; Mc. myocardıum; Ms. muscle; Sf: secondary filament Scale bar $=20 \mu \mathrm{m}$ 
A comparison of Figs. 1 \& 3 shows that while more than half of the carcasses in Fig. 1 were 1-step PCR positive, none of the wild caught crab carcasses were diagnosed with anything more severe than a Level 2 infection (Fig. 3). The relatively high levels of WSSV infection shown in Fig. 1 are probably due to the high dosage of viral inoculum used in the first part of this study. It is worth noting, however, that the WSSV prevalence in the carcasses in both parts of the study was approximately the same (about $60 \%$ ).

A fairly consistent prevalence of around 60\% was observed in the benthic larvae captured in August and September (Table 2). It is possible that this apparently stable and rather severe natural infection rate of wild mud crab seeds in the coastal waters around southern Taiwan might be persist throughout the year; there is also some evidence that mud crab population in shrimp culture ponds have a persistent WSSV infection rate of around $60 \%$ (G.-H.K. unpubl. data). If so, this is potentially very worrying for farmers because many of the crab seeds they use for stocking earth ponds are caught from the wild. Table 2 also shows that despite the deaths that may be attributed to WSSV during the 2 wk observation period, the prevalence in the live specimens at the beginning was the same as the prevalence at the end. This provides yet more evidence for the persistent and stable dispersal of WSSV in the mud crab population.

Acknowledgements. This work was supported by the Council of Agriculture and National Science Council. We are indebted to Mr Paul Barlow, Miss Kit-Ming Tsang and Miss Amy Lin for their helpful criticism of the manuscript.

Editorial responsibility: Timothy Flegel,

Bangkok, Thailand

\section{LITERATURE CITED}

Chang PS, Lo CF, Wang $\mathrm{CH}$, Kou GH (1996) Identification of white spot syndrome associated baculovirus (WSSV) target organs in shrimp, Penaeus monodon, by in situ hybridization. Dis Aquat Org 27:131-139

Flegel TW (1997) Special topic review: major viral diseases of the black tiger prawn (Penaeus monodon) in Thailand World J Microbiol Biotechnol 13:433-442

Kanchanaphum P, Wongteerasupaya C, Sitidilokratana N, Boonsaeng $V$, Panyim S, Tassanakajon A, Withyachumnarnkul B, Flegel TW (1998) Experimental transmission of White Spot Syndrome Virus (WSSV) from crabs to shrimp Penaeus monodon. Dis Aquat Org 34:1-7

Lo $\mathrm{CF}$, Ho CH, Peng SE, Chen CH, Hsu HC, Chiu YL, Chen YT, Chang CF, Liu KF, Su MS, Wang CH, Kou GH (1996a) Infection of white spot syndrome associated virus (WSBV) in cultured and wild-caught shrimps, crabs and other arthropods. Dis Aquat Org 27:215-225

Lo $\mathrm{CF}$, Leu JH, Ho CH, Chen $\mathrm{CH}$, Peng SE, Chen YT, Chou CM, Yeh PY, Huang $\mathrm{CJ}$, Chou HY, Wang $\mathrm{CH}$, Kou $\mathrm{GH}$ (1996b) Detection of baculovirus associated with white spot syndrome (WSBV) in penaeid shrimps using polymerase chain reaction. Dis Aquat Org 25:133-141

Lo CF, Ho CH, Chen CH, Liu KF, Chiu YL, Yeh PY, Peng SE, Hsu HC, Liu HC, Chang CF, Su MS, Wang CH, Kou GH (1997) Detection and tissue tropism of white spot syndrome baculovirus (WSBV) in captured brooders of Penaeus monodon with a special emphasis on reproductive organs. Dis Aquat Org 30:53-72

Lo CF, Chang YS, Cheng CT, Kou GH (1998) PCR monitoring cultured shrimp for white spot syndrome virus (WSSV) in growout ponds. In: Flegel TW (ed) Advances in shrimp biotechnology. National Center for Genetic Engineering and Biotechnology, Bangkok, p 281-286

Supamattaya K, Hoffmann RW, Boonyaratpalin S, Kanchanaphum P (1998) Experimental transmission of white spot syndrome virus (WSSV) from black tiger shrimp Penaeus japonicus to the sand crab Portunus pelagicus, mud crab Scylla serrata and krill Acetes sp. Dis Aquat Org 32:79-85

Submitted: August 26, 1999; Accepted: January 11, 2000 Proofs received from author(s): March 3, 2000 